Ethos (Jurnal Penelitian dan Pengabdian Masyarakat): 69-74

\title{
Pelatihan Pembuatan Video Profil Komunitas di Lingkungan Sma Bopkri 2 YOGYAKARTA
}

\author{
The Training of Communities Profile Video MAKing AT Bopkri 2 High School Yogyakarta
}

\section{${ }^{1}$ Argo Wibowo, ${ }^{2}$ Jong Jek Siang}

${ }^{1,2}$ Fakultas Teknologi Informasi, Universitas Kristen Duta Wacana, Yogyakarta

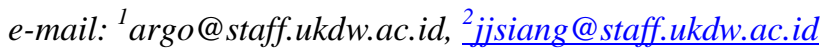

\begin{abstract}
With the development of technology information, the profile of a community/institution became an integral part to declare the existence of a community/institution. No exception in adolescents who are active in various communities. In adolescents, the community profile in form video become a preferred tool because it is easier and dynamic. A short video making that expressed the community profile of high school students needs a video editing techniques. This community service program, official provides training and mentoring for high school students at Bopkri 2 Yogya to make their community's profile. The training was attended by 31 students of class 10 and 11, of which the majority comes from extracurricular photography participants. Students were divided into six groups. Training material includes an explanation of the various types of profiles, using the tools and techniques of video recording, video editing. At the last meeting, students were asked to present the results of the video that has been made. The final result is five community profile videos uploaded to Youtube. Constraints faced is the availability of tools support. Some students do not have a laptop and a recorder with an adequate specification causing the quality of the video is less than the maximum.
\end{abstract}

Keywords: profile, community, video, and technique

\begin{abstract}
Abstrak. Dengan semakin berkembangnya teknologi informasi, profil suatu komunitas/lembaga menjadi bagian tak terpisahkan untuk menyatakan eksistensi komunitas/lembaga tersebut. Tak terkecuali pada remaja yang aktif di berbagai komunitas. Pada kalangan remaja, profil komunitas berbentuk video menjadi alat yang disukai karena pembuatannya yang lebih mudah dan bersifat dinamis. Pembuatan video pendek untuk menyatakan profil komunitas siswa SMU membutuhkan teknik editing video. Dalam program pengabdian masyarakat ini, pengabdi memberikan pelatihan dan pendampingan pada siswa SMA Bopkri 2 Yogya untuk membuat profil komunitas mereka. Pelatihan diikuti oleh 31 siswa kelas 10 dan 11, yang mayoritas merupakan peserta ekstra kurikuler fotografi. Siswa dibagi menjadi 6 kelompok. Materi pelatihan meliputi penjelasan tentang berbagai jenis profil, penggunaan alat dan teknik perekaman video, editing video. Pada pertemuan terakhir, siswa diminta untuk mempresentasikan hasil video yang telah dibuat. Hasil akhir berupa 5 buah video profil komunitas yang diunggah ke media sosial youtube. Kendala yang dihadapi adalah ketersediaan alat pendukung. Beberapa siswa tidak mempunyai laptop dan alat perekam dengan spesifikasi yang memadai sehingga kualitas hasil video kurang maksimal.
\end{abstract}

Kata kunci: profil, komunitas, video, dan teknik

\section{Pendahuluan}

Dunia remaja ditandai dengan banyaknya kegiatan dan keinginan para remaja untuk eksis dan dikenal oleh orang lain. Semakin terkenal seorang remaja, semakin naiklah harga dirinya. Prinsip ini juga berlaku bagi komunitas. Semakin eksis dan aktif komunitas remaja, semakin dikenal pulalah oleh masyarakat. Berbagai cara dilakukan 
remaja, khususnya siswa SMA untuk membuat kegiatan atau komunitasnya terkenal, antara lain dengan aktif memposting kegiatannya dalam media sosial.

Komunitas siswa SMA yang menyadari pentingnya komunitas akan membuat suatu identitas bagi komunitasnya dan berusaha memperkenalkan identitas tersebut pada orang lain. Salah satu cara untuk memperkenalkan identitas dan kegiatan komunitasnya pada orang lain adalah melalui pembuatan sebuah profil bagi komunitas tersebut. Profil dapat dipublikasikan di media sosial sehingga lebih banyak diketahui orang lain.

Pembuatan profil yang bagus tidaklah mudah. Profil yang hanya dibuat asalasalan justru akan menjadi promosi negatif bagi komunitas tersebut. Untuk membuat profil yang bagus diperlukan kemampuan untuk menggabungkan konsep dan teknis editing gambar/video.

Tujuan dari kegiatan pengabdian masyarakat ini adalah untuk memberikan pelatihan bagi siswa SMA agar dapat membuat sebuah profil yang bagus bagi komunitasnya.

Terdapat beberapa kegiatan yang dilakukan:

[1]. Pelatihan tentang konsep pembuatan profil (skenario cerita yang akan disampaikan, kekuatan yang ingin ditampilkan, aktivitas yang dilakukan, dll)

[2]. Pelatihan tentang teknik pengambilan video profil

[3] Pelatihan tentang cara mengedit video sehingga menghasilkan sebuah profil yang siap untuk diunggah

Target yang ingin dicapai dalam pengabdian ini adalah:

[1]. Memberikan kemampuan dasar kepada siswa dalam mengedit video.

[2]. Memberikan kemampuan dasar kepada siswa dalam mempersiapkan dan membuat video profil bagi sekolah

[3]. Memberikan kemampuan dasar kepada siswa untuk dapat mengunggah hasil video editing ke media sosial.

Pengabdian ini dilakukan di SMA Bopkri 2, Yogyakarta kelas 10 dan 11 peserta ekstrakurikuler fotografi. Perangkat lunak yang digunakan dalam pelatihan ini adalah Sony Vegas Pro 12. Installer bagi siswa disediakan oleh tim pengabdian. Ada beberapa luaran dalam pengabdian ini:

[1]. Laporan pengabdian

[2]. Modul pelatihan

[3]. Hasil video unggahan siswa.

Dalam dunia teknologi informasi, multimedia mulai banyak digunakan terutama pada aplikasi yang berbasis web. Penggunaan media baru seperti suara, video dan animasi digunakan sebagai tambahan pada media yang sudah lama digunakan, yaitu teks dan gambar. Penambahan tersebut dapat berperan penting dalam menyajikan informasi yang lebih menarik dan interaktif, tetapi setiap media mempunyai kelebihan maupun keterbatasan penggunaan sebagai berikut.

Video

Schade (2014) menyatakan bahwa tidak ada aturan yang standar bahwa semua pengguna aplikasi langsung menonton video yang ditampilkan pada sebuah halaman web, karena ada beberapa pengguna yang membaca teks yang ada disekitar video terlebih dahulu dan ada yang tidak berminat untuk menonton video yang ditampilkan, sehingga tidak ada jaminan bahwa video yang ditampilkan akan ditonton oleh pengguna secara langsung. Dengan demikian maka pada aplikasi yang akan dibangun pengguna akan diarahkan untuk menonton video resep masakan pada halaman yang berbeda atau 
menekan tombol untuk menonton video yang ditampilkan. Hal tersebut dapat menghindari pengguna yang tidak ingin menonton video secara langsung.

\section{Teks}

Sherwin (2015) menyebutkan beberapa dampak buruk teks yang berkontras rendah pada sebuah halaman web, yaitu sulit dibaca, sulit mendeteksi atau menemukan teks saat pengguna membaca dengan cepat, berkurangnya kepercayaan pengguna, sulit untuk dibaca pada perangkat genggam jika di bawah sinar matahari, aksesibilitas menjadi berkurang apabila digunakan oleh pengguna yang mempunyai gangguan penglihatan dan membutuhkan waktu yang lama untuk menentukan intepretasi yang benar. Teks yang berkontras rendah akan menyebabkan pengguna sulit dalam membaca dan menafsirkan apa yang disampaikan dari teks pada sebuah halaman web, sehingga dalam penggunaan teks yang berkontras rendah harus diperhatikan.

Krug (2013) mengatakan bahwa instruksi merupakan salah satu sumber utama dari kata-kata yang tidak diperlukan, karena tidak ada seorang pun yang akan membacanya. Tetapi jika instruksi tetap diperlukan maka batasilah instruksi menjadi seminimal mungkin, karena instruksi yang terlalu panjang lebar akan mengurangi peluang pengguna dalam menemukan informasi yang diperlukan. Intstruksi-instruksi atau cara pembuatan pada resep merupakan komponen yang tidak dapat dipisahkan dari resep, tetapi dalam menulis instruksi pada resep perlu diperhatikan bahwa instruksi tidak boleh terlalu panjang atau harus berfokus pada instruksi yang benar-benar harus dilakukan oleh pengguna, sehingga pengguna dapat menemukan informasi cara pembuatan dengan mudah dan berfokus pada langkah yang harus dilakukan olehnya.

\section{Audio atau Suara}

Pada aplikasi yang akan dibangun media audio atau suara akan digunakan sebagai masukkan atau dikenal dengan istilah Voice Recognition atau Speech Recognition. Nielsen (2003) memberikan tiga kondisi yang tepat untuk menggunakan suara sebagai masukkan, seperti berikut ini :

1. Pengguna yang disabilitas.

2. Pengguna yang tangannya sibuk.

3. Pengguna yang tidak memiliki akses terhadap keyboard atau monitor.

Aplikasi yang akan dibangun memiliki sebuah fitur untuk memandu pengguna dalam memasak, pengguna yang menggunakan fitur tersebut dapat melakukan kegiatan memasak sekaligus memberikan perintah pada aplikasi untuk menavigasi ke halaman yang diinginkan.

\section{Metode Pelaksanaan}

Langkah-langkah pelatihan pembuatan video profil adalah sebagai berikut :

Langkah pertama melakukan koordinasi pengabdi untuk :

[1].Menentukan materi dan perangkat lunak

[2]. Pembagian jadwal dan tugas

[3]. Pemilihan asisten dll.

Sedangkan langkah kedua yang dilakukan adalah kordinasi dengan pihak SMA Bopkri 2 untuk menentukan jadwal dan proses pelatihan. Hasilnya disepakati dilakukan 6 kali pertemuan dengan materi seperti berikut:

[1]. Pembuatan modul dan persiapan pelatihan

[2]. Pelaksanaan pelatihan.

[3]. Pembuatan laporan 
Jadwal pelaksanaan pengabdian yang dilakukan dapat dilihat pada tabel 1 .

Tabel 1. Jadwal Pengabdian yang disepakati

\begin{tabular}{|l|l|}
\hline Pertemuan & Materi \\
\hline Pertemuan 1 & Pengenalan video profil, pembagian kelompok \\
\hline Pertemuan 2 & Diskusi dan perbaikan skenario, Pengenalan alat perekam \\
\hline Pertemuan 3 & Teknik pengambilan gambar, Pengenalan Sony Vegas Pro \\
\hline Pertemuan 4 & Editing video \\
\hline Pertemuan 5 & Presentasi, diskusi hasil pekerjaan siswa, perbaikan video \\
\hline Pertemuan 6 & Diskusi hasil video siswa \\
\hline
\end{tabular}

\section{Hasil dan Pembahasan}

\section{Pelatihan}

Pelatihan dilakukan selama 6 kali pertemuan dengan waktu dan materi seperti yang tampak pada tabel 1. Presensi peserta dapat dilihat pada lampiran. Pada pelatihan pertama, siswa langsung dibagi menjadi beberapa kelompok dan siswa menentukan komunitas yang akan dibuat profilnya.

Tabel 2. Rincian Kegiatan Pengabdian

\begin{tabular}{|l|l|c|}
\hline \multicolumn{1}{|c|}{ Hari/ Tanggal } & \multicolumn{1}{|c|}{ Materi } & $\begin{array}{c}\text { Jumlah Siswa } \\
\text { Hadir }\end{array}$ \\
\hline Rabu, 30 Maret 2016 & Pengenalan video profil, pembagian kelompok & 28 \\
\hline Kamis, 14 April 2016 & $\begin{array}{l}\text { Diskusi dan perbaikan scenario, pengenalan alat } \\
\text { perekam }\end{array}$ & 18 \\
\hline Selasa, 19 April 2016 & $\begin{array}{l}\text { Teknik pengambilan gambar, pengenalan Sony } \\
\text { Vegas Pro }\end{array}$ & 17 \\
\hline Jumat, 22 April 2016 & Editing video & 23 \\
\hline Selasa, 3 Mei 2016 & $\begin{array}{l}\text { Presentasi, diskusi hasil pekerjaan siswa, } \\
\text { perbaikan video }\end{array}$ & 20 \\
\hline Selasa, 10 Mei 2016 & Diskusi hasil video siswa & 16 \\
\hline
\end{tabular}

Rincian materi pelatihan yang diberikan pada tiap pertemuan adalah sebagai berikut:

Pertemuan 1:

a. Siswa diberi penjelasan tentang profil dan bagaimana langkah-langkah pembuatannya.

b. Siswa diminta membuat kelompok berdasarkan interest kegiatannya (3-5 siswa/kelompok). Siswa diberi tugas untuk membuat skenario cerita yang akan disampaikan, kelebihan dan penekanan yang ingin ditampilkan, detil aktivitas yang akan ditampilkan. 
Pertemuan 2:

a. Hasil skenario cerita didiskusikan dan diberi pengarahan untuk memperbaiki yang masih kurang.

b. Siswa diajarkan tentang teknik perekaman video/gambar

c. Siswa mempraktekkan perekaman video/gambar untuk keperluan pembuatan profil

d. Siswa diberi tugas untuk merekam aktivitas komunitas

Pertemuan 3 - 4:

a. Siswa diajarkan teknik mengedit video. Siswa mempraktekkannya dengan mengedit video yang telah dibuatnya

b. Siswa diberi tugas untuk menyempurnakan video yang dibuat, serta menambahkan aktivitas yang kurang

Pertemuan 5-6: Tiap kelompok mempresentasikan video profil komunitas yang telah dibuat serta dilakukan diskusi. Hasil diskusi dipakai siswa untuk menyempurnakan profil yang dibuatnya.

Setelah pelatihan selesai, siswa diminta untuk mengunggah video profil tersebut ke dalam halaman situs youtube dengan kata kunci SI@UKDW Goes to BODA: <<Nama Profil >>. Setiap anggota kelompok siswa yang mengunggah videonya diberi sertifikat. Berikut ini adalah tautan video yang sudah dibuat oleh para siswa:

[1]. Tautan halaman untuk video profil komunitas karawitan dapat dilihat pada halaman :https://www.youtube.com/watch?v=YJEDJpYijNg

[2]. Tautan halaman untuk video profil komunitas kecantikan Boda dapat dilihat pada halaman :https://www.youtube.com/watch?v=se3gBn7rhMA

[3]. Tautan halaman untuk video profil komunitas Ekstrakurikuler COB (Cheers of Boda) dapat dilihat pada halaman :https://www.youtube.com/watch?v=Pfd1imiiuRQ [4]. Tautan halaman untuk video profil komunitas photography dapat dilihat pada halaman :https://www.youtube.com/watch?v=aHI1f5lvPXY

[5]. Tautan halaman untuk video profil komunitas Band of Boda dapat dilihat pada halaman :https://www.youtube.com/watch?v=_Swl-d8MKf4

Berikut ini adalah salah satu dokumentasi selama dilakukan pengabdian pelatihan pembuatan video profil di SMA Bopkri 2 Yogyakarta.

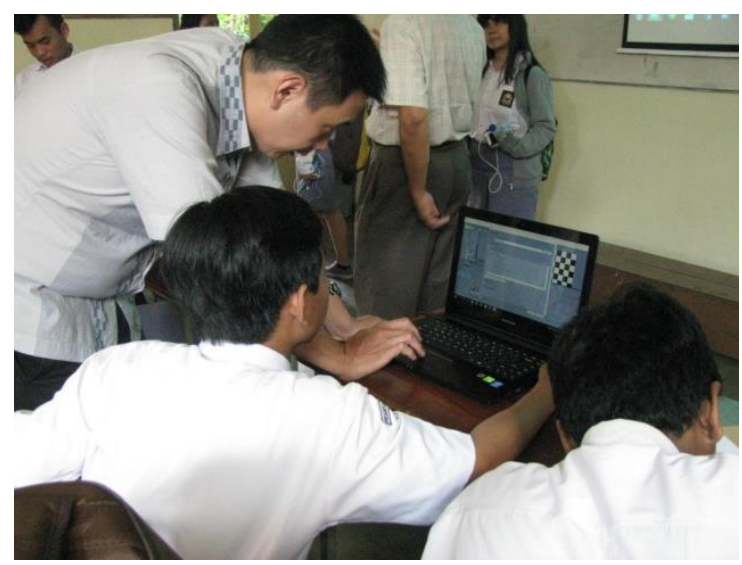

Gambar 4.1: Suasana Diskusi Pelatihan Video Editing 


\section{Kesimpulan}

Dari hasil pengabdian untuk remaja SMA BOPKRI 2 Yogyakarta dapat disimpulkan, antara lain kegiatan pengabdian ini sangat disambut positif baik oleh pihak sekolah maupun pihak siswa SMA Bopkri Dua sebagai peserta. Kegiatan ini dapat memberikan kemampuan tambahan bagi siswa SMA Bopkri 2, terutama dalam hal pembuatan video profil dan video editing. Kegiatan pengabdian ini juga dapat meningkatkan kerjasama yang telah terjalin selama ini antara pihak Fakultas Teknologi Informasi dengan pihak SMA Bopkri 2 Yogyakarta. Selain itu juga dapat meningkatkan pengenalan Fakultas Teknologi Informasi ke siswa SMA di Yogyakarta.

\section{Ucapan Terima Kasih}

\section{Daftar pustaka}

Krug, S. (2013). Don't Make Me Think! Jakarta: PT SERAMBI ILMU SEMESTA.

Nielsen, J. (2003, January 27). Voice Interfaces: Assessing the Potential. Retrieved from Nielsen Norman Group: https://www.nngroup.com/articles/voice-interfacesassessing-the-potential/. Data diakses pada 26 Juli 2016s

Schade, A. (2014, November 16). Video Usability. Retrieved from Nielsen Norman Group: https://www.nngroup.com/articles/video-usability/. Data diakses pada 26 Juli 2016

Sherwin, K. (2015, June 7). Low-Contrast Text Is Not the Answer. Retrieved from

Nielsen Norman Group: https://www.nngroup.com/articles/low-contrast/. Data diakses pada 26 Juli 2016 